\title{
Are financial cooperatives crowded out by commercial banks in the process of financial sector development?
}

\section{Anaïs Périlleux, Annabel Vanroose and Bert D'Espallier}

This paper investigates whether financial cooperatives are crowded out by commercial banks in the process of financial sector development. We use a selfconstructed database (1990-2011) of financial cooperatives in 55 developing countries. Our empirical results are threefold. First, financial cooperatives tend to reach more members in countries where the commercial banking sector is weak. This validates their role as a market failure solution. Second, in the process of commercial bank expansion, financial cooperatives run the risk of being crowded out. Third, financial cooperatives seem to benefit from some kind of bank presence, especially as far as savings mobilization is concerned.

Keywords: Financial cooperatives, Microfinance, Competition, Crowding out, Financial Sector Development

JEL Classifications: G21, L31, O16, P13

CEB Working Paper No 16/002

January 2016 


\title{
Are financial cooperatives crowded out by commercial banks in the process of financial sector development?
}

\author{
Anaïs Périlleux \\ Université Catholique de Louvain (UCL) \\ IRES, CIRTES and CERMi \\ Place Montesquieu, 3, 1348 Louvain-la-Neuve, Belgium \\ anais.perilleux@uclouvain.be \\ Annabel Vanroose \\ Université libre de Bruxelles (ULB), CERMi \\ Vrije Universiteit Brussel (VUB) \\ Av. Roosevelt 50, 1050 Elsene, Belgium \\ avroose@ulb.ac.be \\ Bert D'Espallier \\ KU LEUVEN, CERMi \\ Warmoesberg 26, 1000 Brussels, Belgium \\ Bert.DEspallier@kuleuven.be
}

Forthcoming in Kyklos*

Keywords - Financial cooperatives, Microfinance, Competition, Crowding out, Financial Sector Development

JEL codes - G21, L31, O16, P13

\footnotetext{
* The authors thank Dirk Bezemer, Timothy Guinnane, Marek Hudon, Panu Kalmi, Marc Labie, Benoît Mahy Marthe Nyssens, Liliana Tangwall, Mélanie Volral, and Ariane Szafarz. This research has been carried out through an Interuniversity Attraction Pole on Social Enterprise (SOCENT) funded by the Belgian Science Policy Office. Anaïs Périlleux has benefited from a postdoctoral grant from the AXA Research Fund. Annabel Vanroose has benefited from a postdoctoral scholarship from the National Bank of Belgium (NBB). The authors also thank WOCCU (World Council of Credit Unions) for having provided the extensive database and for helpful exchanges.
} 


\begin{abstract}
This paper investigates whether financial cooperatives are crowded out by commercial banks in the process of financial sector development. We use a self-constructed database (1990-2011) of financial cooperatives in 55 developing countries. Our empirical results are threefold. First, financial cooperatives tend to reach more members in countries where the commercial banking sector is weak. This validates their role as a market failure solution. Second, in the process of commercial bank expansion, financial cooperatives run the risk of being crowded out. Third, financial cooperatives seem to benefit from some kind of bank presence, especially as far as savings mobilization is concerned.
\end{abstract}




\section{INTRODUCTION}

The idea that everyone has to have access to affordable financial services is widely supported by international development organizations like the World Bank and the United Nations (Cull et al., 2013). Financial sector development is considered to be a necessary precondition for economic growth and poverty alleviation. ${ }^{1}$ In the developing world, there are different types of formal and informal financial institutions (Cull et al., 2013). Among them, financial cooperatives are one of the earliest and most widespread forms of alternative financial institutions across the world (Hollis and Sweetman, 1998; Fonteyne, 2007). Typically they are created to fill a gap left by commercial banks that find it too costly and too risky to lend to poor or rural people. Consequently, they serve financially excluded people and create access to finance for an important number of people. Actually, it is estimated that financial cooperatives serve more than 81 million people in developing countries (WOCCU, 2012).

Beyond their pure financial role, financial cooperatives also play a social role. They are alternative financial institutions pushed by self-help dynamism where values of, democracy, equity and solidarity are a common base (Guinnane, 1994; Branch and Baker, 2000; Armendáriz and Morduch, 2010). They often work for the mutual interest of their members and additionally support the local development of their area. Furthermore, the recent financial crisis has questioned the large size of banks (Schoenmaker and Werkhoven, 2013) and the mainstream banking models (Groeneveld and de Vries, 2009). Different studies have demonstrated the importance to preserve institutional diversity (Hesse and Cihák, 2007; Ayadi et al., 2010; Liikanen et al., 2012; Ferri et al., 2014). Therefore alternative financial institutions are put in the spotlight and the interaction between the two sectors becomes a crucial issue.

One could wonder, indeed, what happens when the commercial banking sector develops. On the one hand, one could expect that the sectors are complementary. The two types of institutions serve other people and synergies between the two sectors make them develop

\footnotetext{
${ }^{1}$ Wang and Wong (2009) show however that the effect of financial investment on economic growth is dependent on the level of human capital in a country.
} 
simultaneously. However, one could also argue that once sufficiently developed, the two sectors start competing. Once commercial banks develop, they become interested in the market served by cooperatives and take over their clients. In this argumentation one could speculate whether financial cooperatives are just a step in financial sector development: they open up the market and then the commercial banks take over crowding them out.

While the cooperative sector in Europe and the US has managed to keep a relatively large market share, cooperatives in these countries were developed in a very different context being protected from market globalization and international competition at the early stage of their development and sometimes benefiting from favorable legislations. In the $19^{\text {th }}$ century, financial market globalization was still low or even inexistent and international competition only started to emerge. As Guinnane (2011) argues the commercial banking model was at the early stages of its development too and large multinational banks did not exist yet. In developing countries, current financial cooperatives face competition from national commercial banks, but also from multinational financial institutions. The last three decades of financial liberalization have increased the presence of foreign banks in developing countries (Balmaceda et al., 2014). Furthermore, in some developed countries, financial cooperatives also benefited from favorable legislations, as was the case for German financial cooperatives (Guinnane, 2002). Even up to now, in the US, credit unions are exempt from federal corporate income taxes (Hansmann, 1996; Wilcox, 2006).

Therefore, in times where institutional diversity is set high at the international agenda, it is extremely valuable to assess how financial cooperatives in the developing world are influenced in the process of overall financial sector development and whether or not they are crowded out by commercial banks.

This paper looks at the relationship between the development of the commercial and cooperative financial sector in developing countries where the level of financial development is still low. Using a hand-collected database based on the World Council of Credit of Unions (WOCCU) ${ }^{2}$ data, we assess the relationship for a panel of 55 countries

\footnotetext{
${ }^{2}$ WOCCU is an international association promoting the development of credit unions and other types of
} 
over the years 1990 to 2011 . To the best of our knowledge this is the first paper that addresses this issue empirically.

Our results hint towards the existence of competition between the two sectors on the macro level. This is, where the development of the commercial banking sector is low, there is a higher development of the cooperative sector in terms of the number of institutions as well as the number of people served. This reaffirms the positive role that cooperatives play in overcoming banking market failure. In countries where the commercial sector is less developed, people associate in cooperatives that play a vital role in creating access to finance. However, in the process of financial development they encounter a risk of being crowded out by commercial banks.

But, the results also suggest a more complex relationship since financial cooperatives seem to benefit from a certain extent of commercial banking activity in the sense that the existence of banks provides them with an infrastructure to secure their savings. Indeed, we find a positive relationship between banking development and the average level of savings cooperatives gather. It could also be that through financial sector development the overall savings culture of the country is positively stimulated, creating a positive spillover effect.

The rest of the paper is organized as follows. Section 2 presents the literature on financial cooperatives and explores the possible relationship between the commercial banking sector and the cooperative one. In Section 3, the data and methodology are explained. Section 4 presents and discusses the empirical results. Section 5 concludes and proposes a number of policy-oriented recommendations.

\section{THE INTERACTION BETWEEN FINANCIAL COOPERATIVES AND COMMERCIAL BANKS}

financial cooperatives around the world. It provides technical assistance to financial cooperatives, advocates for them within international organizations and works with national governments to improve legislation and regulation. WOCCU is mainly funded by its members, which are financial cooperatives (http://www.woccu.org/about). 
The two main challenges for lending institutions are screening valid projects and securing the repayment of loans. Lending institutions often do not possess sufficient information on the project and the morality of the client. This information asymmetry leads to two problems: adverse selection and moral hazard. To overcome those problems and secure the risk they take, commercial banks ask collateral to their borrowers. Potential viable clients, who are not able to provide such a collateral, can become involuntary excluded. This results in suboptimum credit allocation and is generally known as market failure (Stiglitz and Weiss, 1981) $)^{3}$.

Commercial privately owned banks lack especially information on specific groups of individuals such as poor and people living in remote communities, who also are often not able to provide any valuable collateral (Fischer and Ghatak, 2011). Furthermore, privateowned banks are usually not able to monitor poor borrower's behavior and enforce contracts, since they are not part of local society and can be considered as outside financiers (Conning and Udry, 2007). Therefore they lack the ability to impose both financial as well as social sanctions (Besley et al., 1993). In such situation, cooperatives have an efficiency advantage, since they have access to better information about borrowers. Additionally, they have the ability to use a diverse set of sanctions, which are traditionally not available to outside bankers (Guinnane, 2001).

Financial cooperatives can be defined as member-owned institutions that provide financial and social services to their members and the local communities in which they are located (Forker et al., 2014). They have a democratic governance structure and generally apply the one-member one-vote rule. Since, elected members running the cooperative and supervising credit allocation belong to the community, they are able to gather the necessary information on the borrowers. Being aware that loans are made with their savings, all members have also an incentive to monitor neighbors-borrowers. Additionally, they have

\footnotetext{
${ }^{3}$ Contrary to what is predicted by economic theory, the price cannot be used to clear the financial market. Indeed, an increase in the interest rate results in an increase of the credit risk. So the nature of the transaction is affected by the price (Stiglitz and Weiss, 1981).
} 
the ability to mobilize cheap and efficient reimbursement incentive mechanisms. Since members are highly socially and economically interconnected, they can easily punish a bad payer by, for example, stopping social and economic interaction with him (Banerjee et al., 1994). Finally, the transaction costs of these institutions are lower, since they are often based in the community and are partly voluntarily run by their members (Forker et al., 2014).

Another type of organization that has found innovative ways to solve information asymmetries are microfinance institutions (MFIs). By using innovative lending methodologies and new product designs, like for example the group lending methodology or progressive lending through small amounts with weekly or monthly repayments, they have been able to create access to finance for the previously unbanked (Armendariz and Morduch, 2010). These types of organizations, set up during the $1980 \mathrm{~s}^{4}$, were traditionally set up as NGOs, while an increasing number has transformed into more commercial institutions and some fully into commercial banks. Consequently, the term MFIs currently comprises a whole range of institutions. Sometimes, financial cooperatives are also labeled MFIs. However, cooperatives differ in a fundamental manner from them. Cooperatives use their member-owned institutional design to overcome information asymmetries, while traditional MFIs address information asymmetry by innovative lending methodologies. In that sense traditional MFIs are more similar to commercial banks in their institutional design. Since the recent crisis has shown the importance to preserve institutional diversity, we think it is important to treat financial cooperatives as different and therefore focus on the relationship between cooperatives and commercial banks ${ }^{5}$.

According to Kalmi (2007) cooperatives are oriented towards broader social goals, which make them fundamentally different from private investor-owned corporations. The International Cooperative Alliance (ICA) ${ }^{6}$ shows that since financial cooperatives are

\footnotetext{
${ }^{4}$ The most well known MFI is the Grameen Bank in Bangladesh. Other well-known institutions are the BRI in Indonesia and BancoSol in Bolivia (Armendáriz and Labie, 2011).

${ }^{5}$ The relationship between microfinance sector and traditional financial sector development has already been explored by Vanroose and D'Espallier (2013). In the econometric analyses we do control for the extent of the microfinance sector in order to identify their interaction.

${ }^{6} \mathrm{ICA}$ is the international association of cooperatives including any sectors (http://ica.coop; consulted August
} 
member-based and self-governed, there is a positive effects on members' level of human capital. Furthermore, cooperatives actively provide education and training for their members and employees (Périlleux et al., 2012). They also inform the general public about the nature and benefits of cooperation (Ward and McKillop, 2010). Additionally, cooperatives work and support local economic development, since they finance small-scale producers and farmers. Finally, they are committed to community development through investment in philanthropic projects and charities and have a self-help focus (Ryder and Chambers, 2009; Benedikter, 2011).

However, cooperative ownership also has a number of limitations. Since they are memberowned, cooperatives tend to have a higher cost of ownership. Hansmann (1996) argues that the cost of decision-making is increased due to many voters and a lack of efficient management control. This last aspect is even more problematic in developing countries, where members can be illiterate and have generally low qualification to supervise management's accounting activity (Cuevas and Fischer, 2006). Although financial cooperatives avoid owners-depositors agency issues, they have more difficulties to align members' and managers' interests. Due to their social mission, it is more complicated for cooperatives to define clear-cut indicators of managers' performances and incentive mechanisms, this contrarily to commercial banks that can use stock-related compensation mechanisms (Wilcox, 2006).

Moreover, the cooperative members' savings determine to a large extent the lending portfolio. So cooperatives often have limited lending portfolio and they offer a more limited range of products compared to private banks (Guinnane, 2011; Périlleux, 2013). In particular, cooperatives face an important maturity mismatch issue. Their collected savings are typically short-term since poor people save, but are not able to block their savings for a longer period. Therefore it is difficult for cooperatives to provide long-term investment loans.

For the above-mentioned reasons, financial cooperatives are different from private-owned 2015). 
banks. We could define them as complements of the commercial financial sector, since they perform a different role. In this sense, financial cooperatives solve the market failure created by commercial banks and provide additional social benefits to members of society. But, financial sector development, characterized by an increase in the commercial bank branch network and the number of products offered, could eventually crowd out cooperative development, since they offer more advanced products and tend to be less time-consuming. In this aspect, financial sector development would have a negative effect on cooperative finance development.

While cooperatives are often seen as alternatives to commercial banks, the two sectors are not entirely disconnected. Namely, cooperatives in their development process use the commercial banking sector for a number of reasons, which could result in positive synergies between the two segments of the financial sector. Looking at the literature, we can identify three important synergies. First, there is the need to secure savings. For financial cooperatives, the protection of members' savings is crucial. However, many small financial cooperatives, as well as bigger networks, cannot afford to invest in safe infrastructures in order to keep their financial resources protected. So these financial cooperatives often rely on banks to safely store the surplus of their members' savings. Andersen and Malchow-Moller (2006) stress the comparative advantages between funding versus information costs in formal and informal sectors. Thanks to the ownership structure financial cooperatives have lower information costs on their members than banks. However, they have higher deposit costs than banks, the latter having larger and more secure infrastructure. Therefore, cooperatives could make use of the bank's advantage in terms of infrastructure to safely store their surplus. A second synergy between commercial banks and financial cooperatives results from the need for liquidity transfer facilities between local financial cooperatives that are affiliated to a network. ${ }^{7}$ Financial

\footnotetext{
${ }^{7}$ Financial cooperatives grow mainly through networking: local financial cooperatives group themselves in networks with a central apex to benefit from economy of scale, liquidity management facilities, additional supervision ensured by the network, etc. The structure of those networks is heterogeneous. Financial cooperative networks can have two or three-tier nodes, including regional and national central unions. Their level of integration also varies a lot: in highly integrated networks, many tasks and policies are centralized, whereas in decentralized networks, major tasks such as human resources management, and policies, such as the setting of interest rate on loans, continue to be carried out by the local cooperatives (Desrochers and
} 
cooperatives could use the commercial banking system to transfer liquidities from one affiliated cooperative to another. Obviously, banks do not have a branch in every working area of the cooperative network, but still, they are often nation-wide present, which could greatly facilitate the circulation of liquidities inside the cooperative network (Périlleux, 2013). Thirdly, links with the banking system enable financial cooperatives to broaden the scope of services they offer, with products such as salaries domiciliation or remittances transfers. These products require financial cooperatives to have bank accounts or to work as bank subcontractors. The development of remittances services is seen as essential in providing financial services to poorer households (Sukadi Mata, 2012; Aggarwal et al., 2011) and in some countries, financial cooperatives are starting to provide these services as a banks' subcontractor (Evans and Klaehn, 2004). All these positive synergies would predict that cooperatives benefit with the commercial banking sector development.

As shown by Guinnane (2002 and 2011), those positive synergies were present in Germany during the 19th century and financial cooperatives benefited from commercial bank sector development. For example, urban financial cooperatives used the Dresdner Bank as their Central. The Dresdner bank was a large and important nationwide commercial bank providing a huge variety of services with a special department offering liquidity and payment services to financial cooperatives. In particular, Guinnane (2011) explains: 'More concretely, when a cooperative made a loan, it did not send out two men on a motorbike with cash, as some other micro-lenders today are forced to do. The cooperative could write the borrower a check drawn on a Central or commercial bank. And if the borrower wanted cash in excess of what the cooperative had on hand, the cooperative could obtain the cash from its Central via Post Office money transfers.' Financial cooperatives thus benefited from the entire financial infrastructure that came along with commercial bank sector development.

In conclusion, the literature suggests that the interaction between financial cooperative development and commercial bank sector development is complex and can be both

Fischer 2005). 
negative (market failure hypothesis) as well as positive (synergies). So what does reality tell us? If we look at history, during the $19^{\text {th }}$ century financial cooperatives were created to provide financial services to financially excluded people in Europe and North America (Fonteyne, 2007). In those countries, especially the rural areas suffered from a lack of access to finance. Consequently a lot of cooperatives were created in those districts. In cities, certain types of people also had difficulties to access finance, often due to a lack of sufficient collateral. Urban artisans, small shopkeepers, and 'handworkers', were not seen as viable clients to commercial banks. Consequently, they organized themselves into financial cooperatives (Hollis and Sweetman, 1998; Guinnane, 2001). In these countries, financial cooperatives have suffered from isomorphic pressures (Kalmi, 2014): financial development, structural changes, competition, the development of rating agencies and regulatory frameworks have pushed the cooperative sector to progress into bigger structures functioning on a similar basis as classical commercial banks. This trend has opened the debate on cooperative identity, how to preserve it and the role that cooperatives play in financial sector development (Côté, 2001).

The reality in developing countries shows that the cooperative financial sector continues to fill a gap left by the commercial banking sector in the sense that they mainly serve financially excluded people (Rogaly, 1998; Cuevas and Fischer, 2006; Hirschland et al., 2008 ; Hartarska et al., 2012). So, one can wonder what happens when the commercial banking sector further develops and how the possible positive synergies between the two sectors influence the development of both segments. Are financial cooperatives only one step in financial sector development and crowded out by commercial bank growth, or do the two sectors develop simultaneously? In what follows, the empirical analysis tries to reveal the direction of the relationship.

\section{DATA AND METHODOLOGY}


According to World Council of Credit Unions (WOCCU), cooperatives serve more than 81 million people in developing countries. WOCCU assembles statistical information of cooperative institutions all over the world on an annual basis. According to WOCCU (2009:1), their aim is 'to measure credit union growth and member service trends worldwide'. They often collaborate with a number of national representative institutions to obtain a full overview of the state of the financial cooperative sector in one country. ${ }^{8}$ Therefore and since it is the international umbrella of the cooperative movement, we suppose that WOCCU-data represents the general state of development of the financial cooperative sectors over the world.

The WOCCU council employs a comprehensive definition of cooperative finance. In general, they refer to Credit Unions, but specify that credit unions receive various names around the world. The WOCCU-database includes financial cooperatives, SACCOs (Savings and Credit Cooperatives), caisses d'épargne et de crédit, and other small-scale financial organizations working on a cooperative basis. ${ }^{9}$ In general, these institutions are user-owned financial cooperatives that offer savings, credit and other financial services to their members (WOCCU, 2012). The WOCCU only gathers information on financial cooperatives and does not include cooperative banks. ${ }^{10}$ This prevents any double counting between financial cooperative and commercial bank development. Furthermore, in developing countries, they are small-scale financial institutions that traditionally not show up in the World Bank development indicators, as argued by Honohan (2008).

The data on the development of the financial cooperative sector represents an unbalanced panel composed of 55 developing countries for the period from 1990 to 2011 with an average of 21 years per country. Regarding geography, the database includes 25 African Countries (out of 54), 18 Central and Latin American Countries (out of 19) and 12 Asian

\footnotetext{
${ }^{8}$ For instance, the WOCCU-data for West Africa comes from microfinance department of the West African Central Bank, which has the most complete information on West African financial cooperatives.

${ }^{9}$ It includes all "member-owned, not-for-profit financial cooperatives that provide savings, credit and other financial services to their members" (www.woccu.org; consulted August 2015).

${ }^{10}$ This is not the case for India. Therefore, in the empirical analysis (see further below) we have tested with and without India, but the results did not change. We present the test with India, but the test without India is available upon request.
} 
Countries (out of 51) including the most important ones, such as India and Bangladesh, but not China (see Appendix A for details).

In order to test the relationship between commercial financial sector development and the cooperative sector, a panel data regression model is developed. Three dependent variables representing two dimensions of financial cooperative development are calculated. First, two outreach variables are defined to measure the degree of penetration of the cooperative sector at the country level. The Outreach No Members variable indicates the number of people served by the sector. It is obtained by summing up all the members of the financial cooperatives at the country level and dividing it by the country population older than fifteen years ${ }^{11}$. The Outreach No Institutions variable indicates the number of institutions for 100,000 inhabitants. Second, the capacity to mobilize savings is measured: FC Savings. We define this as the average savings per cooperative member. We calculate this variable by dividing the total savings collected by financial cooperatives through the total amount of members. The empirical analysis investigates the impact of the commercial banking sector on these measures, while controlling for different parameters.

The general specification of the model can be presented as follows:

$$
\begin{aligned}
& Y_{i, t}=\alpha+\beta_{1} \text { BANK }_{i, t}+\beta_{2} \text { inflation }_{i, t}+\beta_{3} \operatorname{lnGNI}_{i, t}+\beta_{4} \text { growt }_{i, t}+ \\
& \beta_{5} \text { FDI }_{i, t}+\beta_{6} \operatorname{lnAID}_{i, t}+\beta_{7} \text { popdens }_{i, t}+\mu_{i}+u_{i, t}
\end{aligned}
$$

where $Y_{i, t}$ measures financial cooperative development in terms of the three variables outlined above. The main explanatory variable of interest is labeled $B A N K$ which measures commercial banking sector development in terms of several dimensions (Levine, 2005; Cull et al., 2014). First, the total domestic credit provided by the banking sector expressed in percentage of GDP (Bank Credit) is used. This variable gives an indication of the overall penetration rate i.e. the depth of the commercial banking sector. Secondly, we analyze the impact of the banks' network coverage using two variables: the

\footnotetext{
${ }^{11}$ In the WDI database we find total population and population $>15$ years. We take the last variable since it is mainly this part of the population that makes use of financial services.
} 
number of branches of commercial banks per 100,000 adults (Bank Branch) and the number of automated teller machines per 100,000 adults (Bank ATM).

We control for a number of macro-economic factors that have been demonstrated to influence financial sector development: inflation, GNI per capita, GNI growth rate, aid per capita $(A I D)$ and foreign direct investment in GDP percentage $(F D I)$ and population density (Pop Density is the population per square km) (Ahlin et al., 2011; Cull et al., 2014). We also control for regional disparities by including regional dummies. In addition, we also test the relationship controlling for the extent of the microfinance sector. Finally, $\mu_{i}$ is the unobserved heterogeneous effect capturing the time-invariant unobserved country characteristics and $\mathrm{u}_{\mathrm{it}}$ is the error term.

The data on the macro-environmental factors comes from the World Development Indicators (WDI). This database contains also the traditional measures of financial sector development (Levine, 2005; Cull et al., 2014). We use MIX market data ${ }^{12}$ to construct a proxy to capture the development of the microfinance sector on a country level. Microfinance outreach is the total number of micro-borrowers of MFIs active in one country divided by the total population older than 15 years.

We first estimate the parameters of the regression equation using pooled OLS, Random Effects and Fixed Effects estimation. The Random Effects model takes into account the unobserved difference across countries thereby reducing concerns for omitted variables bias. Additionally, it allows us to control for variables for which we do not have timeseries. We also report the results of the Fixed Effect regressions where this is appropriate. We use clustered standard errors that are corrected for heteroskedasticity and autocorrelation. Next, in order to test the robustness of our results, we run a number of additional tests. First, to reduce concerns for endogeneity-bias resulting from reversed causality in the sense that both sectors influence one another, we run the same regression using instruments. Specifically, we run IV-regressions in which Bank Credit is

\footnotetext{
${ }^{12}$ The Mix market (www.mixmarket.org) is the biggest online MFI database (consulted August 2015).
} 
instrumented by several variables such as the cost of business start-up procedures ${ }^{13}$; number of start-up procedures to register a business; number of procedures to register property; time required to enforce a contract and number of procedures to enforce a contract. These variables are chosen as instruments because they are related to overall financial sector development. They help banks to enforce contracts and help formal enterprises, which are typically the clients of banks (Chen, 2012), to develop. Therefore we can argue that these variables are related to the total amount of credit disbursed by banks, but not directly related to financial cooperative development, since cooperatives use less formal procedures and manage credit default and conflict in a more informal way using peer pressures (Armendáriz and Morduch, 2010). Financial cooperatives typically serve informal enterprises, which cannot provide formal guarantees or regular business plans. In addition, we estimate the parameters of the equation using Hausman-Taylor regressions (Hausman and Taylor, 1981). Basically, this is an IV-approach were instruments are generated from the underlying equation to account for any bias resulting from correlation between the unobserved heterogeneous effect $\mu_{i}$ and the error term $\mathrm{u}_{\mathrm{it}}$.

\section{EMPIRICAL RESULTS AND DISCUSSION}

\subsection{Descriptive relationships between the two financial segments}

Table 1 provides descriptive statistics of the main variables in the sample. This table shows that financial cooperatives, on average, serve $4.5 \%$ of the national population older than fifteen years and there are around 2.7 institutions per 100,000 inhabitants in a country. ${ }^{14}$ Their members have an average savings balance of US\$647. Regarding the development of the commercial financial sector, on average commercial banks in a country distribute an amount of credit that equals $46.72 \%$ of the GDP, and a total of 27 ATMs and 11 branches per 100,000 inhabitants.

\footnotetext{
${ }^{13}$ This is the cost to register a business normalized as a percentage of GNI/cap (WDI-indicators), see Appendix B.

${ }^{14}$ These averages are relatively similar between regions. Financial cooperatives in Latin America serve on average $5.4 \%$ of the population, whereas they serve $4.6 \%$ of the population in Africa and $2.9 \%$ in Asia.
} 


\section{$<$ Insert Table $1>$}

In Table 2 we report univariate correlations and test differences in mean between the cooperative and commercial financial sector variables ${ }^{15}$. In general we observe a negative relationship between the development of the cooperative and commercial financial sector. Cooperative institutions serve significantly fewer members when more credit is provided by the commercial sector. This both in terms of the correlation (-0.14) and in terms of difference in means: $3.3 \%$ of the population is served by financial cooperatives in the part of the sample that has the highest level of financial development (top 25\%), while almost $5 \%$ of the population is served by cooperatives in the part of the sample with the lowest financial sector development (bottom 25\%). Additionally, there are less cooperative institutions when more credit is provided by the commercial banking sector, although this difference is not statistically significant. All this is in support of the banking failure hypothesis outlined above. Interestingly, where the banking sector is more developed and thus is providing more credit, people tend to save more in cooperatives. This is in line with the previously explained positive synergies between the two segments.

These statistics demonstrate that commercial banking and financial cooperatives influence each other and the relationship seems to be negative. In contrast, financial cooperatives' ability to collect savings is positively correlated with commercial finance development. To investigate these relationships in more depth a multivariate analysis is exerted in what follows.

$<$ Insert Table $2>$

\subsection{The role of commercial bank sector development}

We first look at the impact of the development of the commercial banking sector, in terms

\footnotetext{
${ }^{15}$ Simple correlation tests between the different variables measuring cooperative development demonstrate a positive relationship between outreach and number of cooperatives. Additionally, there is a positive correlation between financial cooperatives' outreach and the different variables measuring commercial financial sector development.
} 
of Bank Credit on the outreach of financial cooperatives. Regressions (1), (2) and (3) ${ }^{16}$ in Table 3 show that financial cooperatives reach significantly more members in countries where the banking sector is less developed. An increase of 1 percentage-point (or \%-point) in Bank Credit leads to a 0.03 percentage-point (or \%-point) reduction in cooperative members. This result is consistent when controlling for macro-economic variables as well as for population density and regional disparities. The results indicate that the overall level of credit disbursed by the banking sector is negatively related with the outreach of financial cooperatives. Cooperatives are reaching more members in countries where the banking sector is weak. With the expansion of the banking sector, the outreach of financial cooperatives diminishes. This is in line with Vanroose and D'Espallier (2013) who do a similar analysis for the microfinance sector. Just as microfinance institutions, financial cooperatives seem to solve the market failure created by commercial banks but are negatively influenced by deepening of the commercial financial sector. The results suggest that although these alternative financial institutions through their member-based approach are committed to their member needs, the costs for members, in terms of time and involvement, are high (Hansmann, 1996). Furthermore, the financial cooperative's lending portfolio is mostly limited to the savings of their members. Therefore, once commercial banks are more developed they can provide services at a lower cost and offer a wider range of products (Guinnane, 2011), making them attractive.

Regarding outreach in terms of institutions, columns (4), (5) and (6) confirm the negative relationship but, in line with the univariate statistics, the effect is only significant in the OLS regression and not in the RE of FE-regressions. Overall, we can conclude that the number of cooperative institutions is lower in more developed financial countries suggesting that cooperatives stand in some kind of competition with banks. This entails that the number of cooperative institutions reduces as the commercial bank sector develops, although the effect here is smaller than with the number of people served.

\footnotetext{
${ }^{16}$ We see that the joint model statistics (F-stats, $\mathrm{R}^{2}$ ) are much lower and thus less reliable in the FEregressions. Additionally, we investigated the appropriateness of RE-regressions using the 'Breusch-Pagan Langrange Multiplier-test for Random-Effects' which basically assesses the null that the variance of the unobserved effect is zero thus that no random effects is required. The outcome is that the null hypothesis cannot be upheld, suggesting RE is indeed an appropriate method.
} 
Regarding our control variables, especially the level of economic development is significant. The level of GNI per capita positively influences the outreach of cooperatives ${ }^{17}$. This suggests that cooperatives need a certain level of development to start to develop, as also Ahlin et al. (2011) find for microfinance institutions. In order to explore this relationship in more depth, subsection 4.3 presents split-sample regressions and interaction-effects ${ }^{18}$.

$<$ Insert Table $3>$

But first, in order to test the robustness of our results, some of the regressions are reestimated to control for potential causality bias. Indeed, it could be that cooperative development also influences overall financial sector development. As explained in the method section, we account for this by using IV and Hausman-Taylor regressions. Table 4 estimates a 2-step Least Square regression, where Bank Credit is instrumented by cost of business start-up procedures; number of start-up procedures to register a business; number of procedures to register property; time required to enforce a contract and number of procedures to enforce a contract. In general, Table 4 shows similar results to the ones obtained in the standard regressions. The negative relationship is further confirmed, although we only find a significant coefficient for outreach in terms of members. We can thus conclude that reverse causality does not bias our results to a large extent.

Additionally, Table 4, columns (5) and (6), test if the relationship between cooperative sector and commercial financial sector development changes, when we control for microfinance sector development. The general negative relation between the commercial financial sector and the cooperative sector is upheld. Moreover, we cannot find a large influence of microfinance on the development of the cooperative sector. Our data suggests

\footnotetext{
${ }^{17}$ Also AID has a positive and in some cases a significant relationship (IV and HT). Since development aid programs are often directed towards poor and rural communities, the results suggest that it helps to reach a certain level of development and thus also influences positively outreach of cooperatives.

${ }^{18} \mathrm{We}$ also tested the influence the GINI-coefficient has on the relationship. However, no significant relationship could be detected. Furthermore, our number of observations reduces to around 250, so also our model statistics become worse.
} 
that there is no direct clear relationship between microfinance and cooperative development, meaning that the two sectors may be developing independently or mutually. ${ }^{19}$ This is an interesting route for further research.

\section{< Insert Table 4 >}

Overall, these empirical findings support that financial cooperatives are institutions that are capable of overcoming market failure and reach more clients in countries where the banking sector is weak, this way creating access to finance for an important number of people. However, an expansion of the banking sector negatively influences the outreach of financial cooperatives by reducing the need for cooperative finance and negatively influences cooperative development. In what follows, we explore in depth how the level of economic development influences these relationships.

\subsection{Overall level of economic development}

Research suggests that the overall level of development influences financial sector development (Levine, 2004 ; Claessens and Laeven, 2005 and Ahlin et al., 2011; among others). Also institutional differences may play a significant role (Dort et al., 2014). In order to assess the influence of the overall level of development of an economy, which is traditionally correlated with the quality of institutions, we investigate this relationship more into depth. In order to test whether relationships change depending on the level of economic development, we split our sample of developing countries into a subsample of countries with the $25 \%$ of highest GNI/cap and the $25 \%$ of lowest GNI/cap. ${ }^{20}$ Table 5 also assesses the interaction between Bank Credit and the dummyGNIhigh, which takes 1 if the country

\footnotetext{
${ }^{19}$ The OLS regression gives a $10 \%$ significant positive coefficient, so more microfinance, more cooperative development, while the relationship between financial cooperatives and the commercial banking sector does not significantly change. This result would suggest that there is room for both the microfinance and the cooperative sector to develop. However, MIX market data catches a wide range of institutions (in some countries some financial cooperatives may be considered MFIs), so we do not want to draw any final conclusions from these data as there may be some overlap between the two sectors. The specific relationship between financial cooperatives and microfinance sector development is an interesting route to be explored in future research.

${ }^{20}$ We have also conducted split-samples tests for institutional differences using the ICRG political risk indictor as conducted in the paper of Dort et al. (2014), but we have found no significant difference between samples of countries with high and low political risk.
} 
belongs to the 25th percentile of countries with the highest GNI per capita, and zero otherwise.

Both analyses suggest that, as countries further develop, the negative relation between the commercial and cooperative financial sector, grows stronger. Indeed, Table 5 shows that the coefficient of Bank Credit is negative and highly significant in the case of the $25 \%$ part of richest countries (column 2), while not in the $25 \%$ poorest part (column 1), and the interaction effect turns out significant (column 3). The Random Effects (column 4) and Fixed Effects (column 5) regressions confirm the significance of the interaction term ${ }^{21}$. Also outreach in terms of institutions (see Appendix C) shows similar results regarding the interaction effect.

These results insinuate that in underdeveloped economies that have low levels of GNI per capita, there is room for both financial segments to develop. The relative low development of the economy, which results in low infrastructural development, seems to make the commercial banking sector underdeveloped and results in a high proportion of unbanked people. However, once economies develop, the two segments seem to stand in more direct competition with each other. This could be explained by the need for larger loan sizes by clients, which is higher in richer economies, and the fact that the infrastructure is often more developed. Therefore it is less costly for banks to reach out in more remote areas, which are often the areas where the cooperatives are active (Hirschland et al., 2008). There is thus less need for cooperative finance as a market failure solution in these countries. This negatively affects cooperative outreach, and is in line with what Ahlin et al. (2011) and Vanroose and D'Espallier (2013) find for the microfinance sector. Ahlin et al. (2011) furthermore find that there is a positive relationship between microfinance development and level of economic development until a certain point. Once economies start to be too developed, there is less demand for small-scale financial products (ibid.). ${ }^{22}$ Cooperative

\footnotetext{
${ }^{21}$ We do not find any significant result for the split-samples though. This could be due to the reduced number of observations.

${ }^{22}$ We also investigated a non-linear effect of Bank Credit by adding the squared term as an extra regressor. But, regardless of the estimation method (pooled OLS, RE, FE) the coefficient on the squared term is always close to zero and never statistically significant.
} 
finance thus seems to be subject to the risk of being crowded out by commercial finance once this sector is sufficiently developed and the overall economy provides sufficient infrastructure, reducing costs for commercial banks and thus reducing financial cooperatives' comparative advantage of reaching out to remote areas.

\section{$<$ Insert Table 5 >}

\subsection{Savings and commercial sector development}

To have a more complete view of financial cooperative sector growth, Table 6 investigates the impact of the commercial banking sector on the ability of financial cooperatives to mobilize savings from their members. Savings is a key element for the sustainability of financial cooperatives (Guinnane, 1994; Branch and Baker, 2000; Armendáriz and Morduch, 2010). Savings is a question of security and proximity: people save more if they are sure that their savings are in a safe place and if they can save on a regular basis without having to walk long distances (and thus have lower transaction costs). In this analysis, we therefore look at banks' network coverage using Bank Branches and Bank ATMs. We again use both pooled-OLS and random-effects methods.

The pooled-OLS regression of Table 6 (column 3 ) shows a positive but insignificant effect of the domestic credit provided by the banking sector on the financial cooperatives ability to collect savings. Banks' network coverage (Table 6, columns (1) and (2)) on the other hand, positively influences the financial cooperatives' ability to collect savings. When the number of bank ATMs increases with one unit per 100,000 inhabitants, the average amount of savings saved by the cooperative members increases with $\$ 20.55$ (which corresponds with a marginal effect of $3 \%$ around the mean). Random-effects regressions (4) and (5) corroborate this positive relationship: financial cooperatives are mobilizing more savings in countries where the banking sector is more geographically present. This could be explained by an overall increase in 'savings habit' with the presence of commercial banks (Sahoo and Das, 2013). This would mean that people are more aware of the importance of monetary savings once the overall financial sector develops (Masson et al., 1998). So the development of the whole banking sector would increase financial literacy (Cole et al., 
2011) and stimulate the overall savings behavior of the population. Since savings mobilization is key to sustainability for financial cooperatives, this spillover effect is an important positive synergy between financial cooperatives and commercial banks. This positive synergy could additionally be explained by the use of bank branches by financial cooperatives to manage money transfers and savings within their own networks. Finally, cooperatives could use bank branches to store their excess savings, also resulting in positive effects on cooperatives' sustainability.

\section{$<$ Insert Table 6 >}

\section{CONCLUSIONS}

Studies have shown the positive impact of institutional diversity on financial sector stability. The importance of this institutional diversity has been highlighted once more through the recent financial crisis. In developing countries, the underdeveloped commercial banking sector has created room for alternative formal and informal institutions serving people who do not have access to commercial bank financial services. A major question is how this institutional diversity tends to be affected by the development of the commercial financial sector in developing countries.

Financial cooperatives are one of the oldest and most widespread types of alternative financial institutions. They were first developed in Europe and North America initially to serve financially excluded people. In the process of financial development, they managed to keep a relatively large market share in the US and several European countries. Although they suffer from isomorphic pressures in those countries, recent studies have stressed their positive impact on the financial sector stability. But, cooperative banks in developed countries were developed in a very different context being relatively protected from market globalization and international competition at the early stage of their development and sometimes benefiting from favorable legislations.

In the process of financial sector development in the developing world, one could wonder 
how financial cooperatives and commercial banks interact. To the best of our knowledge, this paper is the first investigating this interaction empirically using a large database on a global scale.

Our results are threefold. First, they show that financial cooperatives tend to reach more members in countries where the commercial banking sector is weak. This validates the market failure hypothesis: financial cooperatives are real alternatives and serve people that are excluded from the commercial banking sector. Second, our analysis reveals that in the process of commercial bank expansion, financial cooperatives run the risk of being crowded out. They encounter more difficulties to reach a significant number of people. This could partly be explained by the ability of commercial banks to offer a more diverse and flexible set of products (including longer-term investment loans) and to be more costefficient and less time consuming. The overall economic development of the countries also plays an important role: in 'richer' developing economies the two financial segments stand in more direct competition. This could be explained by a lower demand for small-scale financial products in those economies and more developed infrastructure, which results in lower costs for banks wanting to serve more remote areas, which are traditionally served by financial cooperatives. Third, our results reveal a more complex relationship. Financial cooperatives seem also to benefit from some kind of bank presence. Namely, the capacity of financial cooperatives to mobilize savings is bigger in countries with more developed financial sectors. This is especially so in countries where the banks' network coverage is large. This tends to indicate that financial cooperatives use the bank branch network to secure their saving's surplus and potentially use it to manage savings within their own network. A higher bank presence could also generate positive spillover effects increasing the overall private savings habit of the whole population.

Given the increased recognized positive impact of institutional diversity on financial sector stability and the fact that financial cooperatives play a social role too, these results are important for policy makers wanting to support financial cooperatives and lead to a number of policy suggestions. First, setting up an efficient legislation taking into account all ownership models is key to preserve financial institutional diversity. As shown by the 
current discussions in Europe on Basel III, the new banking legislation following the 20072008 financial crisis, this is not easy to do. Legislation is generally designed to fit the dominant model and can create unexpected additional costs for alternative financial institutions (EACB, 2014). As an example, Ferri and Pesce (2012) and Jones and Kalmi (2012) argue that the new European banking legislation creates distortions that may push alternative banking institutions, such as cooperative and savings banks, into business models outside their nature. The legislator in developing countries should develop legislation that takes into account the specific nature of the cooperative and its specific ownership structure.

Second, policy makers should evaluate the risk for financial cooperatives to be crowded out by commercial bank development and assess the relevance of supporting them. This could happen through both financial and technical policies. Cooperatives could be excluded or be subject to special fiscal policies. These measures could also be used to stimulate networking of small local financial cooperatives, a way for them to scale up and share certain management or administrative tasks and make use of economies of scale, without compromising their cooperative nature. Moreover, financial cooperatives in developing countries often suffer from a lack of technical capacities and insufficient qualified human resources. Therefore, support programs to help them to get better in these matters could be set up.

Finally, policies favoring the positive synergies between commercial banks and financial cooperatives could be implemented. Our results suggest that the possibility to secure savings positively influences the sustainability of the cooperatives. This relationship could be further exploited and facilities to stimulate securing savings should be further developed. As discussed, synergies with banks can also help financial cooperatives to broaden the scope of services they offer, with products such as salaries domiciliation or remittances transfer favoring savings collection. Also facilities for liquidity transfers inside cooperative networks are important. An adequate regulation could help these types of synergies to be further developed. Additionally, incentives for banks to create alliances with financial cooperatives could be stimulated, either through technical support or fiscal 
policy. Cooperatives could also be directly supported in the construction of these types of alliances with commercial banks.

Our study evidently faces a number of limitations that offer some interesting routes for further research. First, our analysis is a macro analysis, so it gives a general tendency and tends to assess certain relationships but does not give evidence of the specific drivers of this relationship. Second, since the information on cooperatives is aggregated on a country level it makes impossible to control for individual institutional characteristics. Future studies could investigate the relationship between financial cooperatives and the banking sector more deeply using disaggregated information at the level of the cooperative. Second, the interaction between financial cooperatives and banks could be explored at a more micro level. Country case studies could certainly shed an additional light on the more complex relationships between the two sectors. Thirdly, it could be interesting to look at the emergence of social and ethical banks in the developed countries (Cornée and Szafarz, 2014), which are often organized as cooperatives in the aftermath of the financial crisis. These events have demonstrated the importance and necessity of alternative models of financial institutions and could eventually result in a revival of the cooperative sector. 


\section{REFERENCES}

Andersen, T. and Malchow-Moller, N. (2006). Strategic Interaction in Undeveloped Credit Markets. Journal of Development Economics, 80, 275-298.

Aggarwal, R., Demirguc-Kunt, A. and Martınez Perıa, M. S. (2011). Do Remittances Promote Financial Development?. Journal of Development Economics, 96, 255-264.

Ahlin, C., Lin, J. and Maio, M. (2011). Where does Microfinance Flourish? Microfinance Institutions' Performance in Macroeconomic Context. Journal of Development Economics, 95, 105-120.

Armendáriz, B. and Morduch, J. (2010). The Economics of Microfinance. Cambridge, Massachusetts: MIT Press.

Ayadi, R., Llewelyn, D.T., Schmidt, R.H., Arbak E. and de Groen, W.P. (2010). Investigating Diversity in the Banking Sector in Europe: Key Developments, Performance and Role of Cooperative Banks, Centre for European Policy Studies, Brussels.

Banerjee, A., Besley, T. and Guinnane, T. (1994). Thy Neighbor's Keeper the Design of a Credit Cooperative with Theory and Test. Quarterly Journal of Economics, 109(2), 491515.

Balmaceda, F., Fischer, R. and Ramirez, F. (2014). Financial Liberalization, Market Structure and Credit Penetration. Journal of Financial Intermediation, 23, 47-75.

Benedikter, R. (2011). Social Banking and Social Finance. Answers to the Economic Crisis. Dordrecht, Heidelberg, London, New York: Springer.

Besley T., Coate S. and Loury G. (1993). The Economics of Rotation Savings and Credit Associations. The American Economic Review, 83(4), 792-810. 
Branch, B. and Baker, C. (2000). Overcoming Credit Union Governance Problems. In Westley G. and Branch, B. (ed.). Safe Money: Building Effective Credit Unions in Latin America. Washington, Inter American Development Bank, 203-226.

Chen, M. A. (2012). The Informal Economy: Definitions, Theories and Policies. WIEGO Working Paper No 1, Harvard Kennedy School.

Claessens, S. and Laeven, L. (2005). Financial Dependence, Banking Sector Competition, and Economic Growth. Journal of the European Economic Association 3(1), 179-207.

Cole, S., Sampson, T. and Zia, B. (2011). Prices or Knowledge? What Drives Demand for Financial Services in Emerging Markets? The Journal of Finance, 66(6), 1933-1967.

Conning, J. and Udry, C. (2007). Rural Financial Markets in Developing Countries. In R. Evenson, P. Pingali, and T. Schultz (eds.). The Handbook of Agricultural Economics, Vol. 3, Agricultural Development: Farmers, Farm Production and Farm Markets, NorthHolland: Elsevier, 2857-2908.

Cornée, S., and Szafarz, A. (2014). Vive la Différence: Social Banks and Reciprocity in the Credit Market, Journal of Business Ethics, 125, 361-380.

Côté, D. (2001). Les Holdings Coopératifs: Evolution ou Transformation Définitive?. de Boeck University, Brussels.

Cuevas, C. and Fischer, K. (2006). Cooperative Financial Institutions - Issues in Governance, Regulation, and Supervision. World Bank-WP, No 82. Washington DC.

Cull, R., Demirgüç-Kunt, A. and Morduch, J. (2013). Banking the World. Empirical Foundations of Financial Inclusion, Cambridge, Massachusetts: MIT Press.

Cull, R., Demirgüç-Kunt, A. and Morduch, J. (2014). Banks and Microbanks. Journal of 
Financial Services Research, 46(1), 1-53.

Desrochers, M. and Fischer, K. (2005). The Power of Networks: Integration and Financial Cooperative Performance. Annals of Public and Cooperative Economics, 76 (3), 307-354.

Dort, T., Méon, P.-G. and Sekkat, K. (2014), Does Investment Spur Growth Everywhere? The Role of Good Institutions, Kyklos, 67 (4), 482-505.

Evans, A.C. and Klaehn, J. (2004). A Technical Guide to Remittances - The Credit Union Experience. WOCCU Technical Guide, No. 4, Madison.

European Association of Co-operative Banks, 2015. Annual Report for 2014. http://www.eurocoopbanks.coop.

Ferri, G. and Pesce, G. (2012). Regulation and the Viability of Cooperative Banks, in Brassard M-J. and Molina E. (eds.) The Amazing Power of Cooperatives. Quebec, Canada: Quebec International 2012 Summit of Cooperatives, 325-340.

Ferri, G., Kalmi, P. and Kerola, E. (2014). Does bank ownership affect lending behavior? Evidence from the Euro area. Journal of Banking \& Finance, 48, 194-209.

Fischer, and Ghatak (2011), In Armendáriz B, Labie M (eds). The Handbook of Microfinance. London: Scientific Press, 77-100.

Fonteyne, W. (2007). Cooperatives Banks in Europe - Policy Issues. International Monetary Fund - WP, 07/159.

Forker, J., Grosvold, J. and Ward, A. M. (2014). Management Models and Priorities in Member Associations: Is Credit Unions' Community Involvement Crowded-Out? Nonprofit and Voluntary Sector Quarterly, 43(2S) 105S-123S. 
Groeneveld, H. and de Vries, B. (2009). European Co-operative Banks: First Lessons of the Subprime Crisis. Rabobank-WP.

Guinnane, T. (1994). A Failed Institutional Transplant: Raiffeisen's Credit Cooperatives in Ireland, 1894-1914. Explorations in Economic History, 31(1), 38-61.

Guinnane, T. (2001). Cooperatives as Information Machines: German Rural Credit Cooperatives, 1883-1914. Journal of Economic History, 61(02), 366-389.

Guinnane, T. (2002). Delegated Monitors, Large and Small: Germany's Banking System, 1800-1914. Journal of Economic Literature, 40(1), 73-124.

Guinnane, T. (2011). The Early German Credit Cooperatives and Microfinance Organizations Today: Similarities and Differences. In Armendáriz B, Labie M (eds). The Handbook of Microfinance. London: Scientific Press, 77-100.

Hansmann, H. (1996). The Ownership of Enterprise. Cambridge, Massachusetts: The Belknap Press of Harvard University.

Hartarska, V., Nadolnyak, D. and Shen, X. (2012). Efficiency in Microfinance Cooperatives. Iberoamerican Journal of Development Studies, 1(2), 52-75.

Hausman, J. and Taylor, W. (1981). Panel Data and Unobservable Individual Effects. Econometrica, 49(6), 1377-1398.

Hesse, H. and Cihák, M. (2007). Cooperative Banks and Financial Stability. International Monetary Fund -WP, 07/2, Washington DC.

Hirschland, M., Jazayeri, A. and Lee, N. (2008). Reaching the Hard to Reach: Comparative Study of Member-Owned Financial Institutions in Remote Rural Areas. Coady International Institute, Canada. 
Hollis, A. and Sweetman, A. (1998). Microcredit: What Can We Learn from the Past? World Development, 26(10), 1875-1891.

Honohan, P. (2008). Cross-country Variation in Household Access to Financial Services, Journal of Banking and Finance, 32, 2494-2500.

Kalmi, P. (2007), The Disappearance of Cooperatives from the Textbooks, Cambridge Journal of Economics, 31, 625-647.

Kalmi, P. and Jones, D. (2012). Economies of Scale Versus Participation: a Co-operative Dilemma? Journal of Entrepreneurial and Organizational Diversity, 1(1), 37-64.

Kalmi, P. (2014). Ethics, Banking and Ownership. Save Bank, 2(55), 27-37.

Levine, R. (2005). Finance and Growth : Theory and Evidence. In Aghion, P. and Durlauf, S. (ed.). Handbook of Economic Growth, vol. 1A, Elsevier, 866-934.

Liikanen, E., Bänziger, H., Campa, J., Gallois, L., Goyens, M., Krahnen, J., Mazzucchelli, M., Sergeant, C., Tuma, Z., Vanhevel, J. and Wijffels, H. (2012). Final Report, High-Level Expert Group on Reforming the Structure of the EU Banking Sector. Brussels.

Masson, P.R., Bayoumi, T. and Samiei, H. (1998). International Evidence on the Determinants of Private Savings. The World Bank Economic Review, 12, 483-501.

Périlleux, A., Hudon, M. and Bloy, E. (2012). Surplus Distribution in Microfinance: Differences Among Cooperative, Nonprofit, and Shareholder Forms of Ownership. Nonprofit and Voluntary Sector Quarterly, 41(3), 386-404.

Périlleux, A. (2013). Strategic Governance Lessons from History for West African Microfinance Cooperatives: a Way to Encourage Investments in Rural Areas. Strategic 
Change, 22, 95-106.

Rogaly, (1998). Combating Financial Exclusion Through Co-operatives: Is There a Role for External Assistance? Journal of International Development, 10, 823-836.

Ryder, N. and Chambers, C. (2009). The Credit Crunch - Are Credit Unions Able to Ride out the Storm? Journal of Banking Regulation, 11, 76-86.

Sahoo, P. and Dash, R.K. (2013). Financial Sector Development and Domestic Savings in South Asia. Economic Modelling, 33, 388-397.

Schoenmaker, D. and Werkhoven, D. (2013). The Impact of Multinationals on the Size of the Banking System. Kyklos, 66(3), 378-397.

Stiglitz, J., \& Weiss, A. (1981). Credit Rationing in Markets with Imperfect Information. The American Economic Review, 71(3), 393-410.

Sukadi Mata, R. (2012). Microfinance and Remittances. Reflets et Perspectives de la Vie Economique, 51(3), 115-127.

Vanroose, A. and D'Espallier, B. (2013). Do Microfinance Institutions Accomplish their Mission? Evidence from the Relationship Between Traditional Financial Sector Development and Microfinance Institutions' Outreach and Performance. Applied Economics, 45, 1965-1982.

Wang, M. and Wong, S. (2009). What Drives Economic Growth? The Case of CrossBorder M\&A and Greenfield FDI Activities, Kyklos. 62(2), 316-330.

Ward, A. M. and McKillop, D. (2010). Profiling: a Strategy for Successful Volunteer Recruitment in Credit Unions. Financial Accountability \& Management, 26(4), 367-391. 
Wilcox, J. (2006). Credit Union Conversions to Banks: Facts, Incentives, Issues and Reforms. Filene Research Institute, USA.

WOCCU (2012). Statistical Rapport 2012. World Council of Credit Unions, Madison, Wisconsin. 


\section{LIST OF TABLES}

Table 1

Summary statistics

\begin{tabular}{|c|c|c|c|c|c|c|}
\hline & & $n$ & mean & median & $\min$ & $\max$ \\
\hline \multicolumn{7}{|l|}{ Financial cooperatives } \\
\hline Outreach No Members & $\begin{array}{l}F C \text { members in country divided by } \\
\text { population }>15 y\end{array}$ & 937 & 4.5 & 2.3 & 0.002 & 42.62 \\
\hline Outreach No Institutions & FC institutions per 100,000 inhabitants & 956 & 2.68 & 1.04 & 0.001 & 45.37 \\
\hline FC Savings & $\begin{array}{l}F C \text { savings in USD divided by } F C \\
\text { members }\end{array}$ & 934 & 647 & 263 & 0 & 14,614 \\
\hline \multicolumn{7}{|l|}{ Commercial financial sector } \\
\hline Bank Credit & domestic credit as \% of GDP & 1,131 & 46.72 & 36.47 & 0.18 & 319.53 \\
\hline Bank ATMs & \# ATMs per 100,000 inhabitants & 280 & 26.72 & 16.01 & 0 & 270.12 \\
\hline Bank Branches & branches per 100,000 inhabitants & 343 & 10.94 & 7.72 & 0.38 & 58.66 \\
\hline \multicolumn{7}{|l|}{ Macro-economic controls } \\
\hline Inflation & annual \% change in consumer prices & 970 & 9.87 & 7.01 & 0.31 & 57.03 \\
\hline GNIcap & GNI per capita in 2005 PPP-adjusted \$ & 1,012 & 4,524 & 3,354 & 75.86 & 27,611 \\
\hline GNIgrowth & annual \% change in GNI per capita & 1,042 & 2.19 & 2.48 & -75.94 & 188.79 \\
\hline FDI & $\begin{array}{l}\text { net inflow foreign direct investment in } \% \\
\text { of GDP }\end{array}$ & 1,107 & 2.78 & 2.08 & 0 & 17.13 \\
\hline Aid & $\begin{array}{l}\text { development aid received in USD } \\
\text { divided by population }\end{array}$ & 1,168 & 36.81 & 23.03 & 0.01 & 250.68 \\
\hline Popdensity & people per square $\mathrm{km}$ of land & 1,180 & 122.48 & 57.98 & 1.71 & 1,156 \\
\hline
\end{tabular}


Table 2

Relationship between financial cooperative sector and commercial financial sector: correlation and T-test analyses

\begin{tabular}{lclcccc}
\hline & Correlation & \multicolumn{4}{c}{ Difference of means } \\
\hline & Bank Credit & \multicolumn{4}{c}{ Bank Credit } \\
& & & High & Low & T-test \\
\hline $\begin{array}{l}\text { Outreach No Members } \\
\text { No obs }\end{array}$ & $\mathbf{- 0 . 1 3 8 * * *}$ & Mean & 0.033 & 0.049 & $3.30^{* * *}$ \\
& 912 & No obs & 240 & 207 & \\
Outreach No Institutions & $\mathbf{- 0 . 0 3 9}$ & Mean & 1.86 & 1.95 & 0.656 \\
No obs & 931 & No obs & 257 & 203 & \\
& & & & & \\
FC savings & $\mathbf{0 . 2 0 6 * * *}$ & Mean & 1086 & 292 & $-7.45^{* * *}$ \\
No obs & 910 & No obs & 248 & 203 & \\
\hline \multicolumn{4}{c}{ Notes: High is defined as top 25\%, Low defined as bottom 25\%. }
\end{tabular}

Table 3

Baseline regression results

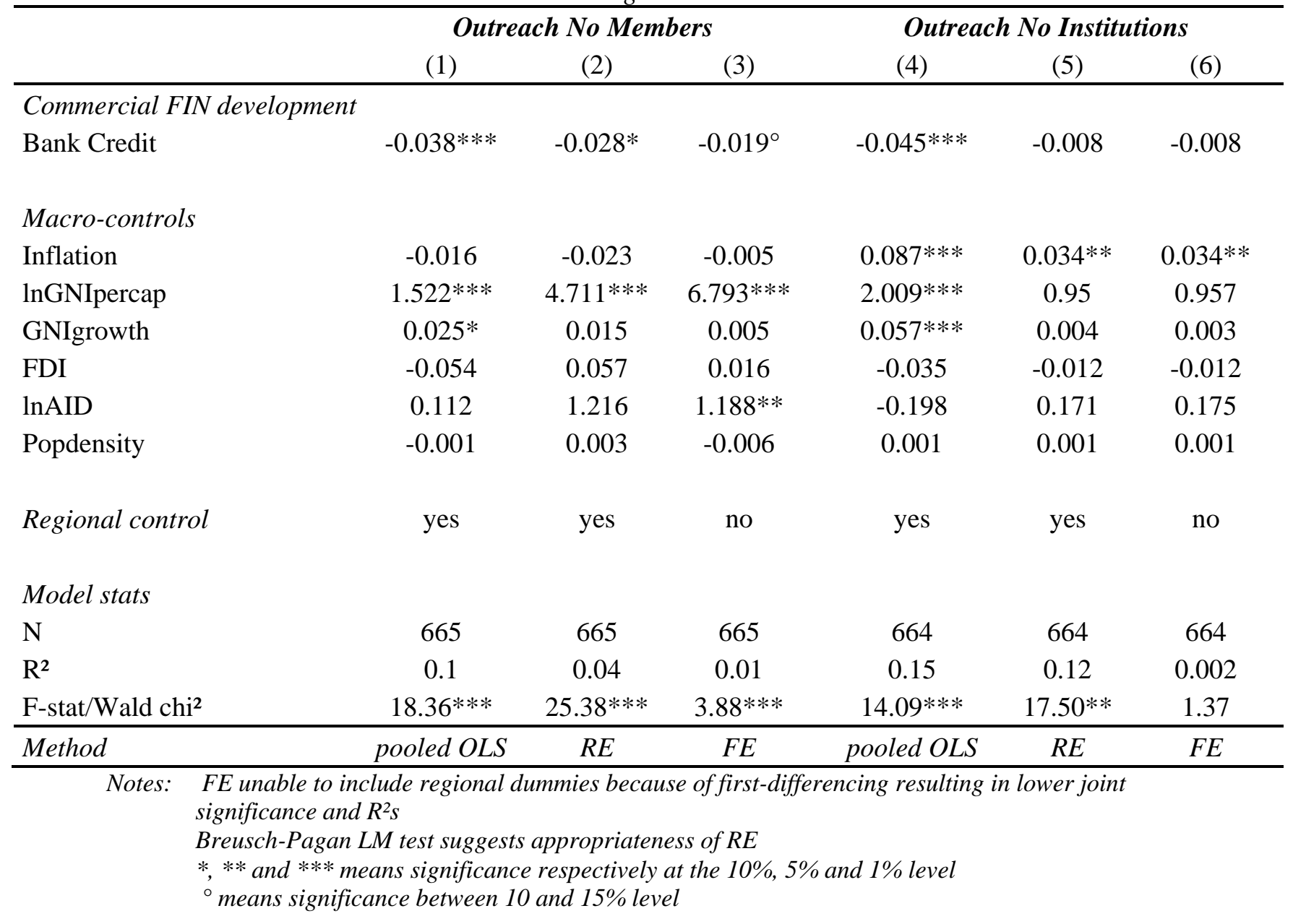


Table 4

Accounting for endogeneity using instruments: $2 S L S$ and HT-approach

And controlling for Microfinance Outreach

\begin{tabular}{|c|c|c|c|c|c|c|}
\hline & \multicolumn{2}{|c|}{$\begin{array}{c}\text { Outreach } \\
\text { No Members }\end{array}$} & \multicolumn{2}{|c|}{$\begin{array}{c}\text { Outreach } \\
\text { No Institutions }\end{array}$} & \multicolumn{2}{|c|}{$\begin{array}{c}\text { Outreach } \\
\text { No Members }\end{array}$} \\
\hline & (1) & (2) & (3) & (4) & (5) & (6) \\
\hline \multicolumn{7}{|l|}{ Commercial FIN } \\
\hline Bank Credit & $-0.223 * * *$ & $-0.020 *$ & $-0.038 * * *$ & -0.003 & $-0.041 *$ & $-0.215^{* * *}$ \\
\hline \multicolumn{7}{|l|}{ Macro-controls } \\
\hline Inflation & -0.019 & -0.012 & $0.026^{*}$ & $0.028 * * *$ & 0.058 & -0.051 \\
\hline lnGNIpercap & $6.898 * * *$ & $5.806 * * *$ & $1.262 * *$ & $0.667 * * *$ & $4.499 * * *$ & $6.449 * * *$ \\
\hline GNIgrowth & 0.016 & 0.009 & 0.006 & 0.01 & 0.074 & 0.047 \\
\hline FDI & -0.176 & 0.036 & $-0.036^{*}$ & -0.018 & 0.016 & -0.051 \\
\hline $\ln A I D$ & $1.108 * *$ & $1.363 * * *$ & $0.199 *$ & 0.09 & $1.534 * *$ & $0.918^{*}$ \\
\hline Popdensity & 0.001 & 0.001 & 0.001 & -0.001 & 0.001 & -0.006 \\
\hline Microfinance Outreach & & & & & 0.095 & 0.233 \\
\hline Regional control & yes & yes & yes & yes & yes & yes \\
\hline \multicolumn{7}{|l|}{ Model stats } \\
\hline $\mathrm{N}$ & 276 & 665 & 289 & 742 & 367 & 223 \\
\hline $\mathrm{R}^{2}$ & 0.10 & & 0.14 & & 0.05 & 0.11 \\
\hline F-stat/Wald chi ${ }^{2}$ & $34.46^{* * *}$ & $141.33 * * *$ & $27.81^{* * *}$ & $28.67 * * *$ & $23.87 * * *$ & $30.92 * * *$ \\
\hline Sargan-Hansen p-value & 0.001 & & 0.348 & & & \\
\hline First-stage F-test & $8.99 * * *$ & & $8.99 * * *$ & & & \\
\hline Method & 2SLS & HT & 2SLS & HT & $R E$ & $I V$ \\
\hline
\end{tabular}

Notes: In 2SLS bank Credit is instrumented by cost of business start-up; number of formal start-up procedures, number of formal procedures to register property; time required to enforce a contract; number of procedures to enforce a contract.

Validity of instruments assessed using the Sargan-Hansen statistic which tests the null that excluded instruments are correctly excluded from the instrument set.

First-stage F-test asserts joint significance in the first-stage regression of the 2SLS-procedure which regresses the endogeneous variable (bank credit) on the chosen instruments.

$*, * *$ and $* * *$ means significance respectively at the $10 \%, 5 \%$ and $1 \%$ level. 
Table 5

Stronger effect in richer economies

\begin{tabular}{|c|c|c|c|c|c|}
\hline & \multicolumn{5}{|c|}{ Outreach No Members } \\
\hline & $\begin{array}{c}(1) \\
25 \% \\
\text { poorest } \\
\end{array}$ & $\begin{array}{c}(2) \\
25 \% \\
\text { richest } \\
\end{array}$ & $\begin{array}{c}(3) \\
\text { interaction } \\
\text { term } \\
\end{array}$ & $\begin{array}{c}(4) \\
\text { interaction } \\
\text { term } \\
\end{array}$ & $\begin{array}{c}5) \\
\text { interaction } \\
\text { term } \\
\end{array}$ \\
\hline Bank Credit & $0.037^{*}$ & $-0.035^{* * *}$ & $-0.015^{* *}$ & -0.013 & 0.001 \\
\hline Bank Credit* dumGNIhigh & & & $-0.037 * * *$ & $-0.024 * *$ & $-0.026 * *$ \\
\hline lnGNIpercap & & & $2.260 * * *$ & $5.192 * * *$ & $7.459 * * *$ \\
\hline Inflation & -0.061 & $-0.080 * *$ & -0.022 & -0.026 & -0.007 \\
\hline FDI & $-0.419 * *$ & 0.119 & -0.0918 & 0.0421 & 0.006 \\
\hline GNIgrowth & -0.032 & 0.096 & 0.011 & 0.008 & -0.001 \\
\hline $\ln$ AID & -0.386 & $-0.933 * * *$ & 0.045 & $1.172 * *$ & $1.133^{* *}$ \\
\hline Popdensity & 0.001 & $0.005^{* *}$ & -0.001 & 0.002 & -0.011 \\
\hline Regional control & yes & yes & yes & yes & no \\
\hline Constant & 13.00 & $24.49 * * *$ & $-10.10^{*}$ & $-54.36 * * *$ & $-74.63 * * *$ \\
\hline \multicolumn{6}{|l|}{ Model stats } \\
\hline $\mathrm{N}$ & 164 & 166 & 665 & 665 & 665 \\
\hline $\mathrm{R}^{2}$ & 0.089 & 0.320 & 0.120 & 0.188 & 0.196 \\
\hline F-stat/Wald chi ${ }^{2}$ & $5.957 * * *$ & $21.81 * * *$ & $19.50 * * *$ & $26.03 * * *$ & $3.665 * * *$ \\
\hline Model & $\begin{array}{c}\text { pooled } \\
\text { OLS }\end{array}$ & $\begin{array}{c}\text { pooled } \\
\text { OLS }\end{array}$ & $\begin{array}{c}\text { pooled } \\
\text { OLS }\end{array}$ & $\mathrm{RE}$ & $\mathrm{FE}$ \\
\hline
\end{tabular}

Notes: Split sample results are not significant with RE and FE method, this could be due to the reduced number of observations.

$*, * *$ and $* * *$ means significance respectively at the $10 \%, 5 \%$ and $1 \%$ level.

See Appendix C for the results of outreach in terms of institutions. 
Table 6

The relation between savings in cooperatives and proximity/infrastructure of the commercial financial sector

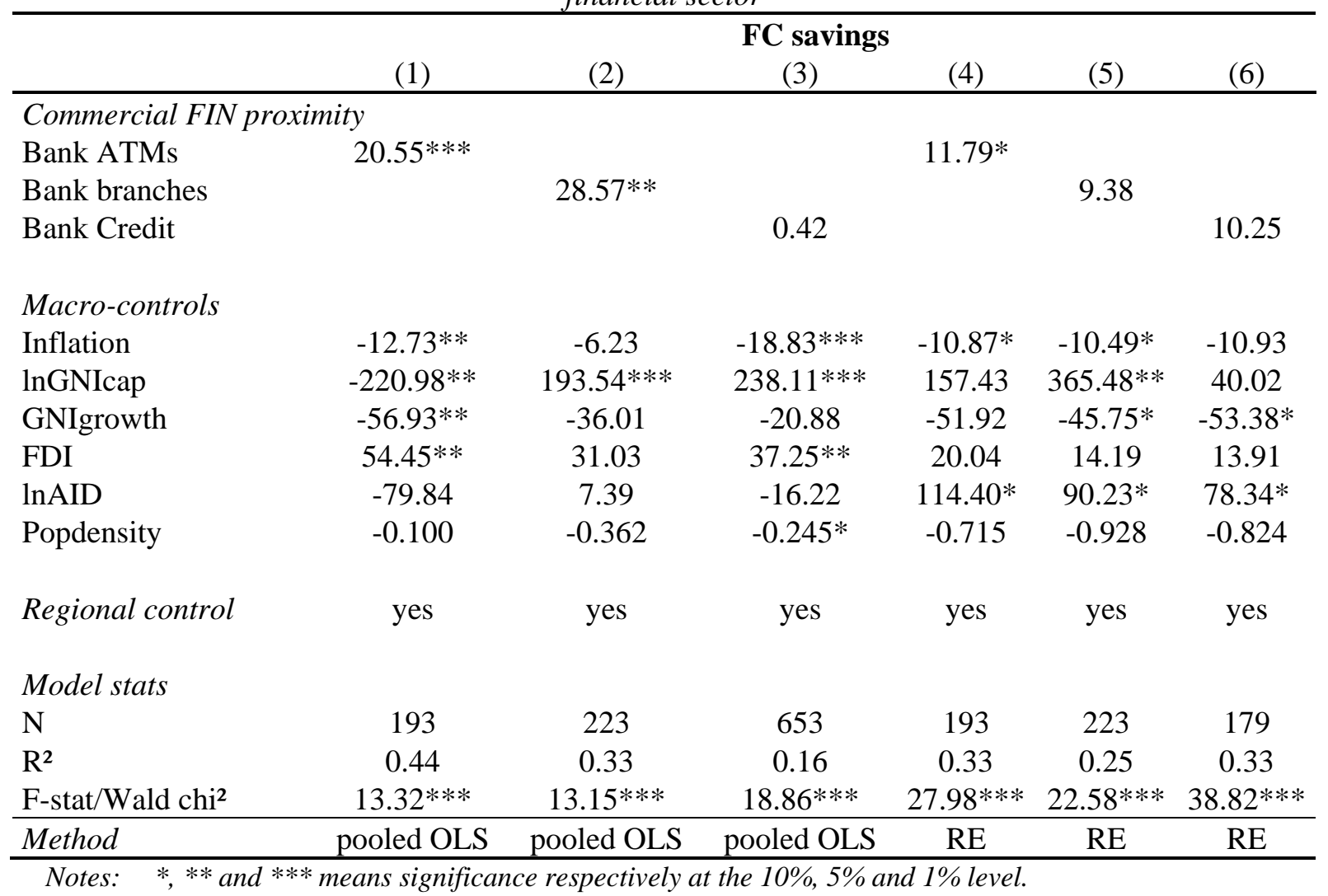




\section{APPENDIX}

\section{Appendix A}

List of the countries and financial cooperative development

\begin{tabular}{|c|c|c|c|c|c|c|c|c|c|}
\hline \multirow[t]{2}{*}{ Country } & \multicolumn{2}{|c|}{$\begin{array}{c}\text { Outreach } \\
\text { No Members } \\
\text { in } \%^{1}\end{array}$} & \multicolumn{2}{|c|}{$\begin{array}{c}\text { Outreach } \\
\text { No Institutions } \\
\text { in } \%^{2} \\
\end{array}$} & \multirow[t]{2}{*}{ country } & \multicolumn{2}{|c|}{$\begin{array}{l}\text { Outreach } \\
\text { No Members } \\
\text { in \% }\end{array}$} & \multicolumn{2}{|c|}{$\begin{array}{c}\text { Outreach } \\
\text { No Institutions } \\
\text { in } \%\end{array}$} \\
\hline & 1990 & 2011 & 1990 & 2011 & & 1990 & 2011 & 1990 & 2011 \\
\hline Argentina & 0.44 & $0.37^{*}$ & 0.07 & $0.05^{*}$ & Mexico & 0.77 & 4.59 & 0.27 & 0.05 \\
\hline Bangladesh & 0.04 & 0.31 & 0.02 & 0.72 & Namibia & $0.20 *$ & $0.18^{*}$ & $1.35^{*}$ & $1.00^{*}$ \\
\hline Benin & 0.19 & 31.08 & 0.27 & 0.43 & Nepal & $0.02 *$ & 3.31 & $0.30 *$ & 3.30 \\
\hline Bolivia & 4.07 & 7.19 & 2.54 & 0.24 & Nicaragua & 0.24 & 1.09 & 0.58 & 0.10 \\
\hline Brazil & 0.41 & 2.98 & 0.24 & 0.39 & Nigeria & 5.02 & $0.62 *$ & 15.38 & $0.04 *$ \\
\hline Burkina Faso & 0.23 & 16.99 & 0.72 & 0.32 & Panama & 6.16 & 4.37 & 6.83 & 4.82 \\
\hline Cameroon & 1.12 & 3.23 & 2.04 & 1.09 & $\begin{array}{l}\text { Papua New } \\
\text { Guinea }\end{array}$ & 3.96 & 9.62 & 0.96 & 0.29 \\
\hline Chile & $1.67 *$ & 8.28 & $0.77^{*}$ & 0.24 & Paraguay & 2.76 & 15.82 & 1.39 & 0.72 \\
\hline Colombia & 1.38 & 6.07 & 0.69 & 0.42 & Peru & 5.71 & 4.92 & 1.41 & 0.54 \\
\hline $\begin{array}{l}\text { Congo, Dem. } \\
\text { Rep. }\end{array}$ & 1.48 & $1.41^{*}$ & 0.39 & $0.42 *$ & Philippines & 0.13 & 6.73 & 0.66 & 1.26 \\
\hline Costa Rica & 5.81 & 17.10 & 1.69 & 1.40 & Rwanda & 8.30 & $11.69 *$ & 1.67 & $1.33^{*}$ \\
\hline Cote d'Ivoire & 0.18 & 14.26 & 0.62 & 0.31 & Senegal & 0.04 & 30.93 & 0.28 & 1.84 \\
\hline $\begin{array}{l}\text { Dominican } \\
\text { Republic }\end{array}$ & 1.58 & 6.00 & 0.93 & 0.15 & Seychelles ${ }^{3}$ & $0.07 *$ & $0.14 *$ & 1.43 & 1.16 \\
\hline Ecuador & $13.44 *$ & 18.07 & $4.49 *$ & 0.23 & Sierra Leone & 0.20 & $0.18^{*}$ & 1.76 & $1.34 *$ \\
\hline El Salvador & 0.70 & 3.71 & 0.88 & 0.51 & South Africa & $0.01 *$ & 0.08 & $0.09 *$ & 0.10 \\
\hline Ethiopia & 0.44 & 0.54 & 1.00 & 5.12 & Sri Lanka & $5.93 *$ & 5.74 & $41.96 *$ & 40.44 \\
\hline Gambia & 0.14 & 4.48 & 1.04 & 3.88 & Swaziland & 1.17 & 5.70 & 1.27 & 5.62 \\
\hline Ghana & 0.69 & 2.05 & 0.99 & 1.69 & Tanzania & 0.74 & 3.66 & 1.52 & 11.37 \\
\hline Guatemala & 1.96 & 11.67 & 0.58 & 0.17 & Thailand & 3.47 & 6.30 & 1.33 & 2.97 \\
\hline Honduras & 2.84 & 13.47 & 1.72 & 1.07 & Togo & 1.17 & 37.24 & 3.41 & 1.41 \\
\hline India & 0.07 & 2.31 & 0.08 & 0.13 & Uganda & 2.30 & 6.47 & 2.38 & 6.12 \\
\hline Indonesia & 0.17 & 1.02 & 0.81 & 0.38 & Uruguay & 5.99 & 4.96 & 1.06 & 0.98 \\
\hline Kenya & 7.23 & 17.47 & 6.74 & 11.15 & Uzbekistan & $0.003^{*}$ & $0.79 *$ & $0.02 *$ & 0.37 \\
\hline Korea & 5.93 & 14.01 & 3.07 & 1.92 & Venezuela & $0.35^{*}$ & $1.47 *$ & $0.47^{*}$ & $1.99 *$ \\
\hline Liberia & 1.73 & 0.72 & 3.34 & 3.03 & Vietnam & $1.53^{*}$ & 2.31 & $1.12^{*}$ & 1.25 \\
\hline Malawi & 0.35 & 1.33 & 1.23 & 0.30 & Zambia & 2.42 & 0.03 & 4.71 & 0.19 \\
\hline Malaysia & 0.17 & 0.85 & 1.70 & 0.06 & Zimbabwe & 0.24 & 1.14 & 1.12 & 0.42 \\
\hline Mauritius & 4.13 & 9.89 & 7.08 & 7.39 & & & & & \\
\hline
\end{tabular}

Notes:

1. Outreach No Members in \% is the sum of all the financial cooperatives' members at the country level divided by the country population older than fifteen years.

2. Outreach No Institutions in \% indicates the number of financial cooperatives in a country for 100,000 inhabitants. 3. Seychelles' Outreach No Members is obtained by dividing the number of financial cooperatives' members by the total population instead of the population older than 15 years.

* means we do not have the figure in the database for the year 1990 or 2011 . We thus report the closest figure from these years. 


\section{Appendix B}

Main outreach and instrumental variables

Variables Explanations

\section{Dependent variables}

\section{Outreach No Members (a/b)}

Financial cooperative members (a)

Population > 15 (b)

\section{Outreach No Institutions (c/d)*100.000}

No financial cooperatives (c)

Population (d)

\section{FC Savings (e/a)}

Total savings (c)

\section{Microfinance outreach (f/b)}

Microfinance clients (f)

\section{Instrumental variables}

Cost of business start-up procedures

Number start-up procedures to register a business

Number of procedures to register property

Time required to enforce a contract

Number of procedures to enforce a contract

\section{The percentage of the population older than 15 year served by financial cooperatives in a country}

The number of people served by the financial cooperatives in a country

The total population older than 15 years (see population for the definition of total population of a country).

\section{The number of financial cooperative institutions for 100,000} inhabitants

The number of financial cooperatives in a country

The population is based on the de facto definition of population, which counts all residents regardless of legal status or citizenship, except for refugees not permanently settled in the country of asylum, who are generally considered part of the population of the country of origin.

\section{The average savings per cooperative member}

Total amount of savings in USD collected by financial cooperatives in a country

The total number of micro-borrowers of MFIs active in one country divided by the total population older than 15 years

The total number of micro-borrowers of MFIs active in one country
Cost to register a business is normalized by presenting it as a percentage of gross national income (GNI) per capita.

Start-up procedures are those required to start a business, including interactions to obtain necessary permits and licenses and to complete all inscriptions, verifications, and notifications to start operations. Data are for businesses with specific characteristics of ownership, size, and type of production.

Number of procedures to register property is the number of procedures required for a businesses to secure rights to property.

Time required to enforce a contract is the number of calendar days from the filing of the lawsuit in court until the final determination and, in appropriate cases, payment.

Number of procedures to enforce a contract are the number of independent actions, mandated by law or courts, that demand interaction between the parties of a contract or between them and the judge or court officer. 


\section{Appendix $C$}

Split samples for outreach in terms of institutions

\begin{tabular}{|c|c|c|c|c|c|}
\hline \multirow[b]{2}{*}{ VARIABLES } & \multicolumn{5}{|c|}{ Outreach No Institutions } \\
\hline & $\begin{array}{c}(1) \\
25 \% \text { poorest }\end{array}$ & $\begin{array}{c}(2) \\
25 \% \\
\text { richest } \\
\end{array}$ & $\begin{array}{c}(3) \\
\text { interaction } \\
\text { term } \\
\end{array}$ & $\begin{array}{c}\text { (4) } \\
\text { interaction } \\
\text { term } \\
\end{array}$ & $\begin{array}{c}5) \\
\text { interaction } \\
\text { term } \\
\end{array}$ \\
\hline $\begin{array}{l}\text { Bank Credit } \\
\text { Bank Credit } * \text { dumGNIhigh } \\
\text { lnGNIpercap }\end{array}$ & 0.009 & 0.007 & $\begin{array}{l}-0.033 * * * \\
-0.020 * * \\
2.403 * * *\end{array}$ & $\begin{array}{c}-0.001 \\
-0.009 * \\
1.172\end{array}$ & $\begin{array}{c}-0.001 \\
-0.009 * \\
1.198\end{array}$ \\
\hline Inflation & $0.060 * * *$ & -0.013 & $0.085^{* * *}$ & $0.034 * * *$ & $0.034 * *$ \\
\hline FDI & 0.030 & $0.267 * * *$ & -0.055 & -0.015 & -0.015 \\
\hline GNIgrowth & -0.023 & -0.020 & $0.050 * * *$ & 0.001 & 0.001 \\
\hline $\ln$ AID & -0.0380 & $-0.577 * * *$ & -0.233 & 0.154 & 0.156 \\
\hline Popdensity & $-0.001 * *$ & $0.009 * * *$ & 0.001 & -0.0001 & -0.001 \\
\hline Regional control & yes & yes & yes & yes & no \\
\hline Constant & 2.696 & $10.57 * * *$ & -9.133 & -8.983 & -9.428 \\
\hline \multicolumn{6}{|l|}{ Model stats } \\
\hline $\mathrm{N}$ & 164 & 165 & 664 & 664 & 664 \\
\hline $\mathrm{R}^{2}$ & 0.167 & 0.726 & 0.149 & 0.0731 & 0.073 \\
\hline F-stat/Wald chi² & $13.54 * * *$ & $62.97 * * *$ & $13.23 * * *$ & $18.66 * * *$ & $1.371 * * *$ \\
\hline Model & $\begin{array}{c}\text { pooled } \\
\text { OLS }\end{array}$ & $\begin{array}{c}\text { pooled } \\
\text { OLS }\end{array}$ & $\begin{array}{c}\text { pooled } \\
\text { OLS }\end{array}$ & $\mathrm{RE}$ & $\mathrm{FE}$ \\
\hline
\end{tabular}

Notes: Split sample results are not significant with RE and FE method, this could be due to the reduced number of observations.

$*, * *$ and $* * *$ means significance respectively at the $10 \%, 5 \%$ and $1 \%$ level. 